\title{
Een nieuw begin
}

Voor $\mathrm{u}$ ligt het eerste nummer van de nieuwe jaargang van het Tijdschrift voor Medisch Onderwijs (TMO). Een bijzonder nummer. Bijzonder omdat we met dit eerste nummer ons beleid om de belangstelling voor TMO onder met name clinici te vergroten, zichtbaar willen maken. In dit kader zijn in overleg met het bestuur van de Nederlandse Vereniging voor Medisch Onderwijs (NVMO) twee belangrijke stappen gezet.

De eerste stap betreft de buitenkant van TMO. Na de ingrijpende gedaanteverandering van TMO enkele jaren geleden bleek in overleg met de uitgever dat de 'uitstraling' van het tijdschrift nog verder verbeterd kon worden. Er is gekozen voor een meer moderne lay-out met een per jaargang wisselende foto. Het is de bedoeling om elk jaar een ander UMC (of andere medische faculteit) te vragen een foto voor de omslag van TMO te leveren. De spits wordt door Utrecht afgebeten. In dit nummer vindt $\mathrm{u}$ een korte toelichting van de Utrechtse redactieleden op de keuze van déze foto.

De tweede stap die gezet is, betreft de binnenkant van TMO. TMO moet aantrekkelijker worden voor artsen die betrokken zijn bij onderwijs en opleiding. Niet alleen aantrekkelijker om te lezen (en dus om lid van de NVMO of abonnee van het tijdschrift te worden), maar ook aantrekkelijker om zelf in TMO te publiceren. Dat betekent overigens niet dat het tijdschrift voor niet-clinici minder aantrekkelijk zou moeten worden. Integendeel. De geschiedenis van de NVMO leert dat onderwijskundigen en vertegenwoordigers van niet-medische disciplines een belangrijke plaats binnen de NVMO hebben. Dat moet ons inziens ook zo blijven. Maar dat neemt niet weg dat de aandacht voor misschien wel de belangrijkste doelgroep van de NVMO, dokters die bij onderwijs en opleiding zijn betrokken, meer aandacht behoeft dan tot op heden het geval is geweest. Daarom een 'specialistennummer' als eerste nummer van de nieuwe jaargang van TMO met bijdragen over het onderwijs aan studenten geneeskunde, de opleiding van medisch specialisten, het raakvlak tussen beide en over algemene onderwerpen die op zowel het onderwijs als de opleiding van toepassing zijn.

Het afgelopen jaar is er in vele rapporten een warm pleidooi gehouden voor een betere en efficiëntere overgang van de opleiding tot basisarts naar de vervolgopleiding. Dit moet onder meer leiden tot een snellere toename van het aantal huisartsen en andere medisch specialisten. Een belangrijke voorwaarde voor een efficiënt opleidingscontinuüm is dat de initiële opleiding tot basisarts en de vervolgopleidingen inhoudelijk goed op elkaar zijn afgestemd. Maar minstens zo belangrijk is dat de methoden waarop onderwijs en opleiding worden vormgegeven beter op elkaar aansluiten. In de meeste UMC's is heden ten dage de opleiding tot basisarts op een moderne leest geschoeid, maar voor de specialistische vervolgopleidingen is dat veelal nog niet het geval. Vele aspecten van de nieuwe onderwijsmethoden 
aan studenten kunnen daarbij tot voorbeeld dienen voor de vervolgopleiding. Natuurlijk heeft de opleiding van artsassistenten haar eigen, veelal zeer functionele kenmerken. Maar dat neemt niet weg dat voor de onderwijskundige onderbouwing van de opleiding van arts-assistenten meer gebruik gemaakt moet worden van de competenties die zij als student in de basisopleiding hebben verworven en de wijze waarop zij hebben geleerd om kennis te verwerven en te verwerken. Een aansluiting ook op dit terrein zal ongetwijfeld bijdragen aan een hoger rendement en waarschijnlijk ook grotere voldoening bij de arts-assistent en zijn/haar opleider.

De besluitvorming binnen het Centraal College Medische Specialismen (CCMS) over de hervorming van de medisch specialistische opleiding vormt een belangrijke impuls daartoe. Zoals in het artikel van Bleker et al. in dit nummer van TMO wordt beschreven, heeft het CCMS aan de hand van het CanMEDS 2000-rapport een zevental kerncompetenties als leidraad voor de opleiding gedefinieerd. ${ }^{1}$ Deze competenties zijn te verdelen in specialisme-gebonden en algemene competenties. Voorts geeft het CCMS duidelijk richting aan de wijze waarop in de één en twintigste eeuw toekomstig medisch specialisten opgeleid dienen te worden. Zo zal bij voorbeeld de feedback tussen AGIO en opleider professioneler moeten, zal cursorisch onderwijs voor praktische en theoretische cursussen een meer structurele plaats moeten krijgen en zullen de vorderingen van de arts-assistent vervolgd moeten worden via regelmatige voortgangstoetsen en besprekingen van een portfolio. Daarmee sluit de door het CCMS bepleite hervorming van de specialistenopleiding aan op de onderwijskundige vernieuwingen van de huidige onder- wijsprogramma's voor geneeskunde studenten. Het opnemen van 'nutteloze' vakken daarbij, zoals in dit nummer bepleit door de filosoof Derkse, levert een bijdrage aan de academische vorming, die een wezenlijk onderdeel van de onderwijs- en opleidingsprogramma's dient te zijn. $^{2}$

Inmiddels zijn de wetenschappelijke verenigingen uitgenodigd om eindtermen van de vakspecifieke onderdelen van die competenties te formuleren. De bedoeling is dat dit proces in de tweede helft van 2005 is afgerond. Het ligt voor de hand dat de algemene competenties die voor alle toekomstig medisch specialisten hetzelfde zijn, meer centraal worden uitgewerkt. Conform het advies in het rapport 'De arts van straks' zou de NVMO een centrale rol moeten spelen bij de ontwikkeling van het onderwijs op het gebied van de algemene competenties. ${ }^{3}$

Bij het geneeskundeonderwijs en de specialistische vervolgopleiding zijn belangrijke ontwikkelingen gaande. De roep om meer artsen is duidelijk en de noodzaak tot een goed, efficiënt en op moderne leest geschoeid opleidingstraject van student tot specialist is daarom groot. De aanbevelingen van de Commissie Implementatie Opleidingscontinuüm en Taakherschikking op dit terrein zijn inmiddels door de minister van VWS overgenomen. ${ }^{4}$ Voor dokters en onderwijskundigen ligt er de uitdaging om gezamenlijk hieraan te werken. Wij hopen dat de NVMO met het Tijdschrift voor Medisch Onderwijs als haar spreekbuis inderdaad de beoogde voortrekkersrol kan spelen.

Om de bekendheid van de NVMO en het TMO te verbreden, is de oplage van dit specialistennummer aanzienlijk groter dan gebruikelijk en wordt dit nummer aan alle opleiders in academische en nietacademische ziekenhuizen toegestuurd. 
De redactie hoopt hiermee de kring van lezers van het tijdschrift en potentiële auteurs onder clinici te kunnen vergroten.

\section{De redactie}

\section{Literatuur}

1. Bleker OP, Cate ThJ ten, Holdrinet RSG. De algemene competenties van de specialist in de toekomst. Tijdschrift voor Medisch Onderwijs 2004; 23(1):4-14.

2. Derkse W. Vruchtbare 'nutteloosheid': het belang van algemene vorming in de context van beroepsgerichte academische opleidingen. Tijdschrift voor Medisch Onderwijs 2004;23(1): 57-63.

3. Meijboom-de Jong B, Schmit Jongbloed LJ, Willemsen MC, editors. De arts van straks - een nieuw medisch opleidingscontinuüm. Utrecht: KNMG/DMW-VSNU/VAZ/NVZ/LCVV; oktober 2002.

4. LeGrand-van den Bogaard MJM, Rooijen APN van, editors. De zorg van morgen - flexibiliteit en samenhang. Rapport van de Commissie Implementatie Opleidingscontinuüm en Taakherschikking. Den Haag: Ministerie van VWS; juli 2003. 